\title{
A Déli-Mátrában végzett gyepkezelési eljárások hatása a magyar aknászpók (Nemesia pannonica Herman, 1879) abundanciájára
}

\author{
Szmatona-Túri Tünde ${ }^{1}$,Vona-Túri Diána ${ }^{2}$ és Magos Gábor ${ }^{3}$ \\ ${ }^{1}$ FM ASzk-Mátra Erdészeti, Mezögazdasági és Vadgazdálkodási Szakképzö Iskolája és \\ Kollégiuma, \\ 3232 Mátrafüred, Erdész út 11. \\ ${ }^{2}$ Eötvös József Református Oktatási Központ, \\ 3360 Heves, Dobó út 29. \\ ${ }^{3}$ Bükki Nemzeti Park Igazgatóság, Mátrai Tájegység, \\ 3304 Eger, Sánc út 6. \\ e-mail: turitunde79@gmail.com
}

\begin{abstract}
Összefoglaló: Munkánk során a kaszálás és a cserjeirtás hatását vizsgáltuk a védett, szubmediterrán elterjedésủ magyar aknászpók (Nemesia pannonica Herman, 1879) abundanciájára a Gyöngyösi Sár-hegy természetvédelmi területen és a Mátrai Tájvédelmi Körzet (Gyöngyössolymos) területén. A mintavételezést 2007-2010 és 2012-2015 között végeztük élvefogó, illetve Barber-csapdás gyüjtéssel, mely során a $N$. pannonica 216 egyedét sikerült begyüjteni. Hím példányai mellett petékkel rendelkező nőstény egyedek is kerültek a csapdákba, mely korábbi vizsgálatokkal ellentétben igazolja, hogy alkalmanként a nőstények is elhagyják tárnáikat. A faj a kaszált és a cserjeirtott területeken jelentősen nagyobb abundanciával volt jelen, mint a kezeletlen élőhelyeken. Adataink alapján elmondhatjuk, hogy az élőhely-rekonstrukciós kezelések kedvező hatással voltak az egyedszám alakulására, ezért a faj megóvásának egyik módja lehet az élőhelyek fenntartása és helyreállítása.
\end{abstract}

Kulcsszavak: kaszálás, cserjeirtás, abundancia, nőstény egyedek

\section{Bevezetés}

A környezet változásaira érzékeny, fajgazdag csoportot képviselő pókok az adott élőhelyekről számos információt szolgáltatnak, ezért a természetvédelmi kezelések hatásának vizsgálatára jól alkalmazhatók. A legtöbb pókfaj speciális környezeti igényekkel rendelkezik, ezért a közösségek összetétele jól jelzi az adott élöhely strukturális változását (Ysnel \& Canard 2000). A különféle kezelések, mint a kaszálás, hatással vannak a pók közösségek összetételére (Pozzi el al. 1998), ezért 
a pókok vizsgálata fontos a tájhasználat és a gyepkezelések megfelelő koordinálásához.

Hazánkban a védett pókfajok száma igen csekély. A 16 védettséget élvező faj közül természetvédelmi szempontból az egyik legértékesebb a magyar aknászpók (Nemesia pannonica Herman, 1879). A 10000 HUF pénzben kifejezett természetvédelmi értékủ szubmediterrán faj elsősorban a középhegységek délre néző oldalain, sziklagyepekben, lejtősztyeppekben és bokorerdőkben fordul elő. Legnagyobb állománya a Szársomlyón (Villányi-hegység) (Szinetár \& Lajos 2000, Lajos \& Vadkerti 2007) található, valamit Budapest környékén és a Sas-hegyen (Balogh 1935, Bleicher et al. 1999) is nagy számban fordul elö.

Több tanulmány szerint a kaszálórétek és a legelők Közép-Európában a legfajgazdagabb élőhelyek közé tartoznak (Steffan-Dewenter \& Leschke 2002, Ilmarinen \& Mikola 2009). Ökológiai szempontú vizsgálataik az utóbbi években nagy figyelmet kaptak. A hegyi rétek esetében az emberi beavatkozás természetvédelmi szempontból nagy jelentőséggel bír, hiszen fenntartásuk és helyreállításuk a gyepkezelési eljárásokkal kivitelezhető. A vegetáció összetételére és szerkezetére a periodikus zavarás, mint például a kaszálás (Hulbert 1988, Maret \& Wilson 2000) befolyással van, kedvező hatását a florális diverzitásra több kutatás is igazolta (Decleer 1990, Buttler 1992, Güsewell et al. 1998, Noordijk et al. 2010).

A tanulmányunk célja az volt, hogy bemutassuk a kaszálás és a cserjeirtás, mint gyepkezelési eljárások hatását a $N$. pannonica egyedszámára. Nyolc év gyüjtési adatai alapján végeztük a vizsgálatot, mely során elsőként igazoltuk a faj mátrai előfordulását (Szmatona-Túri \& Vona-Túri 2012), azonban a gyepkezelés hatására vonatkozó eredményeinket részletesen még nem ismertettük. Adataink természetéből adódóan statisztikai elemzéseket nem állt módunkban elvégezni, ezért csak a kezeléseknek köszönhető évenkénti egyedszám változást mutatjuk be.

\section{Módszerek}

A Mátra déli fekvésủ peremhegyén, a Gyöngyösi Sár-hegy természetvédelmi területen és töle ÉNY-i irányban fekvő gyöngyössolymosi területen (MTK) 2007-2010 és 2012-2015 között végeztünk gyüjtéseket. Mindkettő Natura 2000 terület, előbbi élőhelyvédelmi (Special Area of Conservation), utóbbi madárvédelmi (Special Protection Area) terület. A Gyöngyösi Sár-hegy TT értékes faunája mellett kiemelkedő jelentőségű florisztikai elemekkel is rendelkezik. Az árvalányhajas erdőssztyeppréteken és lejtősztyeppréteken állományalkotó a hoszszúlevelü árvalányhaj (Stipa tirsa), a barázdált csenkesz (Festuca rupicola) és a fogtekercs (Danthonia alpina). Olyan védett fajok élnek, mint a nagyezerjófü 
(Dictamnus albus), a dunai szegfü (Dianthus collinus), a tavaszi hérics (Adonis vernalis) vagy a tarka imola (Centaurea triumfetti). A Mátra hegységben előforduló három Natura 2000 jelölő növényfaj mindegyike megtalálható a Sár-hegyen, ezek a Janka-tarsóka (Thlaspi jankea), a piros kígyószisz (Echium russicum) és a leánykökörcsin (Pulsatilla grandis). A mezofil (víztöblettel befolyásolt) kaszálórétek értékes fajai közé tartozik a kornistárnics (Gentiana pneumonanthe) és az agárkosbor (Orchis morio), valamint a síkvidékről felhúzódott érdekességek, a csikorgófü (Gratiola officinalis) és a sziki kocsord (Peucedanum officinale).

A Sár-hegy kaszált (1-2. ábra) és kontroll sztyepprétjein 2007-2010 között

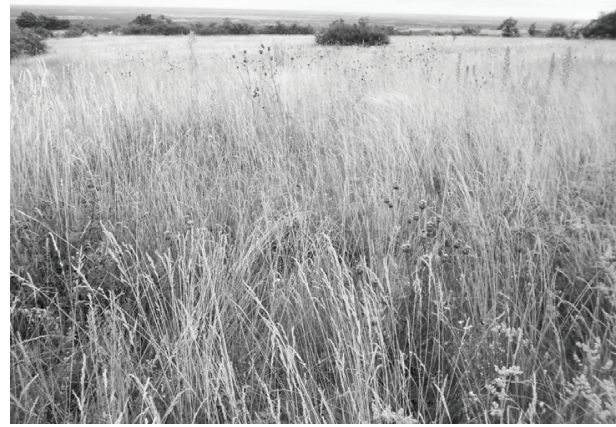

1. ábra. Kaszált élőhely a Sár-hegyen késő nyáron a kaszálás elött.

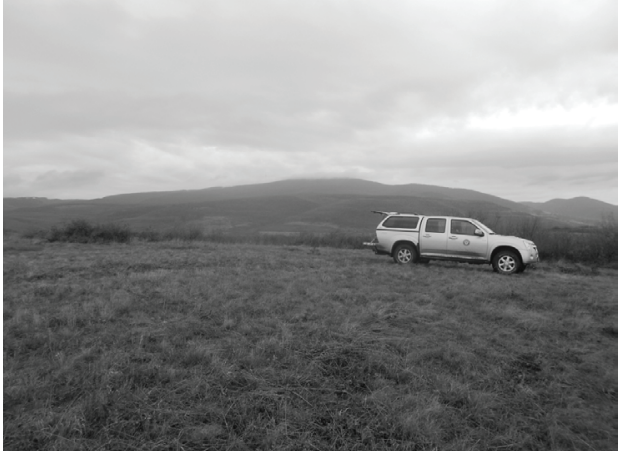

2. ábra. Kaszált élőhely a Sár-hegyen ősszel a kaszálás után.

és 2012-ben vizsgáltuk a kaszálás hatását a faj abundanciájára. A kaszálás és a talajzoológiai monitoring a Bükki Nemzeti Park Igazgatóság koordinálásával és támogatásával valósult meg. A kezelés javarészt gépi kaszálással, évente egy alkalommal, az időjárási viszonyok függvényében ősszel vagy késő nyáron történt. A kezelések során forgó módszert alkalmaztak menedékhelyek és táplálékforrás fenntartása érdekében. 2012-2015 között a Sár-hegyen és Gyöngyössolymoson cserjeirtott (3. ábra), kontroll cserjés, illetve kontroll réteken (lásd. 1-2. ábra)

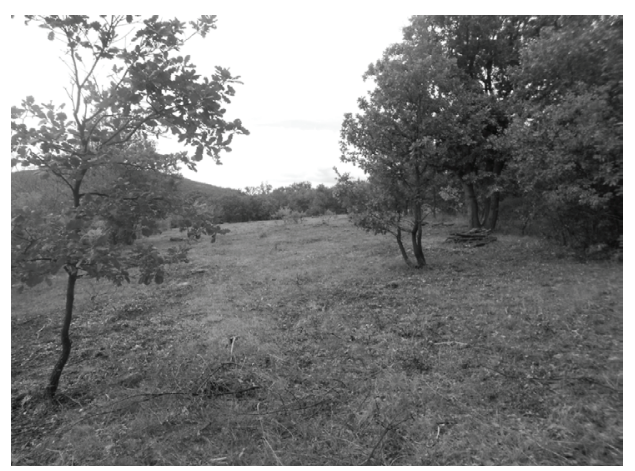

3. ábra. Cserjeirtott élőhely 2013-as évi őszi aszpektusa Gyöngyössolymoson. 
1. táblázat. A mintaterületekre jellemző kezelés módja és vegetáció.

\begin{tabular}{|c|c|c|c|c|c|}
\hline Gyüjtőhely & $\begin{array}{l}\text { Tenger- } \\
\text { szint feletti } \\
\text { magasság } \\
\quad(\sim \mathrm{m})\end{array}$ & $\begin{array}{l}\text { Vizsgálat } \\
\text { célja }\end{array}$ & $\begin{array}{l}\text { Mintavételi } \\
\text { terület }\end{array}$ & $\begin{array}{l}\text { Méret } \\
(\sim \text { ha })\end{array}$ & Társulás \\
\hline \multirow{3}{*}{$\begin{array}{l}\text { Gyöngyös- } \\
\text { solymos }\end{array}$} & \multirow{3}{*}{300} & \multirow{3}{*}{$\begin{array}{l}\text { Cserjeirtás } \\
\text { hatása }\end{array}$} & Kaszálórét & 3 & $\begin{array}{c}\text { Erdős pusztarét (Campanulo- } \\
\text { Stipetum tirsae) }\end{array}$ \\
\hline & & & Cserjés & 3 & $\begin{array}{l}\text { Spontán záródott Pruno spinosae- } \\
\text { Crataegetum erdőssztyepp erdő } \\
\text { elemekkel (pl. Acer tataricum) }\end{array}$ \\
\hline & & & $\begin{array}{l}\text { Cserjeirtott } \\
\text { minta }\end{array}$ & 1 & $\begin{array}{c}\text { Erdős pusztarét(Campanulo- } \\
\text { Stipetum tirsae) }\end{array}$ \\
\hline \multirow{4}{*}{ Sár-hegy } & \multirow{4}{*}{350} & \multirow{2}{*}{$\begin{array}{l}\text { Cserjeirtás } \\
\text { hatása }\end{array}$} & $\begin{array}{l}\text { Cserjeirtott } \\
\text { minta }\end{array}$ & 1 & $\begin{array}{l}\text { (Pulsatillo montanae-Festucetum } \\
\text { rupicolae) }\end{array}$ \\
\hline & & & Cserjés & 1 & $\begin{array}{l}\text { Töviskés cserjés (Pruno } \\
\text { spinosae-Crataegetum) }\end{array}$ \\
\hline & & \multirow[b]{2}{*}{$\begin{array}{l}\text { Kaszálás } \\
\text { hatása }\end{array}$} & Kaszálórét & 5 & $\begin{array}{c}\text { Erdős pusztarét (Campanulo- } \\
\text { Stipetum tirsae) }\end{array}$ \\
\hline & & & $\begin{array}{l}\text { Kontroll } \\
\text { rét }\end{array}$ & 1 & $\begin{array}{c}\text { Cserjés sztyepprét (Pulsatillo } \\
\text { montanae-Festucetum rupicolae - } \\
\text { Pruno spinosae-Crataegetum) }\end{array}$ \\
\hline
\end{tabular}

vizsgáltuk a cserjeirtás hatását (1. táblázat). A kezelések a KEOP (Rétek, gyepek, legelők helyreállítása és kezelése) projekt keretein belül valósultak meg, a talajzoológiai vizsgálatot a Bükki Nemzeti Park Igazgatóság támogatta. A cserjék irtása kézi erővel, egy alkalommal történt 2012 őszén, melyet további kezelések nem követtek, ezért a 2015-ös évben egy homogén, alacsony cserjékkel borított társulás alakult ki.

A vizsgálat során duplaedényes talajcsapdákkal végeztük a mintavételezést, melyhez tetővel lazán fedett $10 \mathrm{~cm}$ átméröjü, müanyag poharakat alkalmaztunk. 2007-2012 között a terület természetvédelmi jellegére, az ott előforduló védett fajokra tekintettel, élvefogó csapdákat használtunk. A csapdák egy évben négy alkalommal (április, május-június, augusztus-szeptember, november) két héten keresztül voltak kihelyezve. Az élőhelyek négy oldalára, a szegélytöl kb. $5 \mathrm{~m}$ távolságra 3-3 csapda lett kihelyezve, melyeket egymástól $4 \mathrm{~m}$ távolságra rendeztünk el. A Bükki Nemzeti Park Igazgatóság közremüködésével 2012-2015 között etilén-glikollal töltött, Barber-csapdákkal végeztünk gyüjtéseket, melyek évente két alkalommal (május, szeptember), három héten keresztül müködtek. Területenként 5 darab csapdát helyeztünk ki, egymástól 4-5 m távolságra egy transzekt mentén. Az élvefogó csapdákat 48 óránként, a Barber-csapdákat kéthetente ürítet- 
tük. A Barber-csapdával gyüjtött egyedek mellett az élve fogott egyedek kb. fele konzerválásra került 75\%-os etil-alkohollal. A szabad szemmel könnyen azonosítható egyedeket szabadon engedtük. A konzervált példányok jelenleg még a BNPI Mátrai Tájegységénél lettek elhelyezve.

\section{Eredmények}

2007-2010 között a Sár-hegyről a N. pannonica 59 egyedét sikerült kimutatnunk, mely során elsőként igazoltuk a faj mátrai előfordulását (Szmatona-Túri \& VonaTúri 2012). A 2012 és 2015 között további 157 példányát gyüjtöttük be a Sár-

2. táblázat. A N. pannonica előfordulási adatai a Déli-Mátra élőhelyein.

\begin{tabular}{ccccccccccc}
\hline \multirow{2}{*}{ Gyüjtöhelyek } & \multicolumn{4}{c}{ Kaszálás vizsgálata } & \multicolumn{5}{c}{ Cserjeirtás vizsgálata } & \multirow{2}{*}{ össz. } \\
& 2007 & 2008 & 2009 & 2010 & 2012 & 2012 & 2013 & 2014 & 2015 & \\
\hline Sár-hegy & 6 & 2 & 36 & 25 & 17 & 73 & 16 & 8 & 4 & 187 \\
Gyöngyössolymos & & & & & & 1 & 25 & - & 3 & 29 \\
\hline
\end{tabular}

hegyröl és Gyöngyössolymosról (2. táblázat). Mind a kaszált, mind a cserjeirtott élőhelyeken jelentősen nagyobb abundanciával volt jelen, mint a kezeletlen élöhelyeken. A kaszálás legszembetűnőbb hatása a 2010-es évben figyelhető meg, ahol a kaszált réteken 21, a kontroll réteken pedig csak 4 egyede került elö. A cserjeirtott élőhelyeken is jelentős egyedszámbeli fölény tapasztalható, főként a 2013-as évben. A cserjeirtott élőhelyeken 25, a cserjésekben 4 egyed volt jelen (4. ábra). A faj legtöbb egyedét a Gyöngyösi Sár-hegy TT-en mutattuk ki. Hím pél-

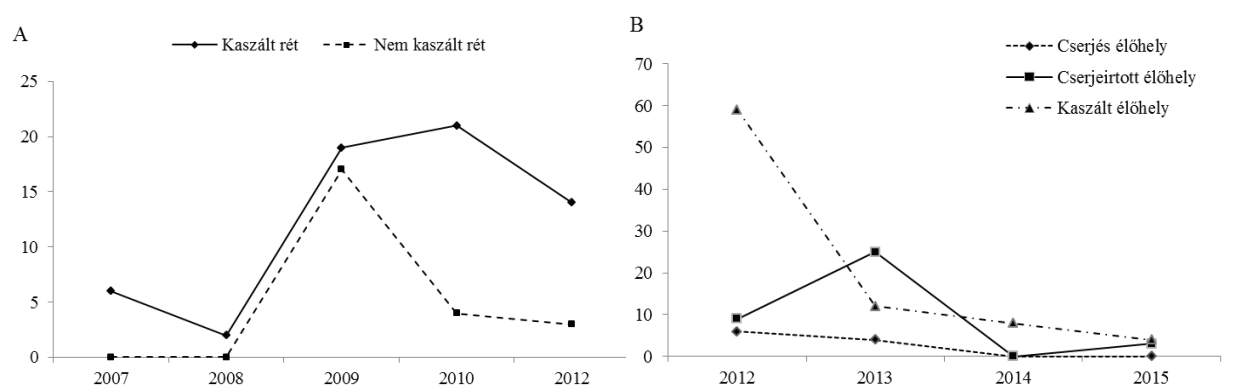

4. ábra. A N. pannonica abundanciája (A) kaszált és nem kaszált, illetve (B) cserjés -, cserjeirtott és kaszált élőhelyeken.

dányai mellett egy, petékkel rendelkező nőstény is került a talajcsapdákba Gyöngyössolymoson. A jelen kutatással párhuzamosan zajló faunisztikai vizsgálatunk 
során egy másik nőtényt is sikerült begyüjteni a Sár-hegy egyik déli élőhelyéröl (5. ábra).

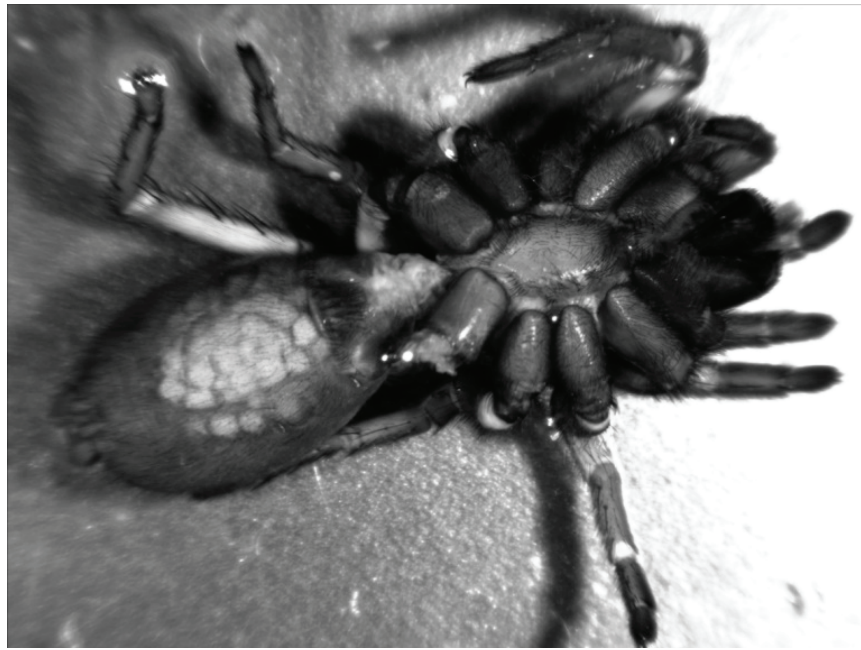

5. ábra. A $N$. pannonica nőstény példánya petékkel.

\section{Értékelés}

A déli-mátrai élőhelyeken a magyar aknászpók jelentős állományát sikerült felfedeznünk. Az első 4 év (2007-2010) gyüjtési adatai korábbi munkánkban (Szmatona-Túri \& Vona-Túri 2012) már publikálásra kerültek, melynek fó célja a magyar aknászpók első mátrai előfordulásának ismertetése és szezonalitás vizsgálata volt. Jelen munkánk kiegészíti a korábbi tanulmányt további gyűjtésekkel és gyepkezelési hatásvizsgálattal.

A Sár-hegyről a nyolc éves gyüjtésünk során minden évben került elő $N$. pannonica egyed. Korábbi vizsgálatok szerint (Loksa 1984, Lajos \& Vadkerti 2007) a nőstények egész életüket tárnáikban töltik, így gyüjtésük talajcsapdával nem lehetséges. Adataink bizonyítják, hogy esetenként a nőstény egyedek is elhagyhatják tárnáikat. Ennek hátterében valószínüleg nem lokális hatás áll, mivel az egyik nőstény a Sár-hegy tavaszi mintájában volt jelen, a másik Gyöngyössolymosról került elő egy őszi gyüjtés során. Ez alátámasztja korábbi, hímek aktivitása alapján kimutatott eredményeinket (Szmatona-Túri \& Vona-Túri 2012), mely szerint a fajnak egy évben két, tavaszi és őszi szaporodási időszaka van.

A $N$. pannonica minden élöhely típusban elöfordult, azonban a kezelt és a kezeletlen habitatokban az egyedek száma nagymértékben eltért. A kaszált és cserjeirtott élőhelyeken tapasztalt nagyobb abundancia - szemben a kezeletlen élö- 
helyekkel - tükrözi a kezelések kedvező hatását a faj számára. Szinetár et al. (2012) a Budai Sas-hegyen végzett vizsgálatához hasonlóan, a kezelések hatására a faj állománya növekedésnek indulhat, mivel a cserjés területek helyén létrejövő nyílt gyepek kedvezőbb feltételeket biztosítanak a faj számára. A kezelt és kezeletlen területek közötti egyedszámbeli eltérés egyes években kimagasló volt. A 2010, 2012-es években a kaszált és nem kaszált élőhelyek közötti nagy eltérést az magyarázhatja, hogy a szeptemberi gyüjtéseket megelőzte a kaszálás ellenben a többi évekkel, ezért egy alacsony fümagasságú élőhely jött létre, mely kedvezett a faj számára (2. ábra). A cserjeirtott élőhelyeken a kezelést követő évben (2013) a faj abundanciája nőtt, így a kezeletlen élőhelyhez viszonyítva nagy eltérés mutatkozott. A további kezelések hiánya miatt a következő években (2014-2015) a számuk csökkent. Elmondható tehát, hogy a cserjeirtást követő kaszálás elmaradása a faj visszaszorulását eredményezheti, ezért javasoljuk a BNPI számára a kezelések átgondolása és pótlását, melyet 2016-ban el is végeztek. Az évek közötti egyedszámbeli eltéréseknek a feltételezhető oka az lehet, hogy a $N$. pannonica tavaszi és őszi aktivitási csúcsa az adott év időjárásviszonyai miatt elcsúszhat. A megfigyeléseink alapján az árpilisi és szeptemberi gyüjtések akkor voltak eredményesek, amikor az idojjárás megfelelt az adott hónapnak. A meleg és száraz szeptember alkalmával nem sikerült egyedeket gyüjteni.

Összességében elmondható, hogy a területen zajló élőhely-rekonstrukciós kezelések hatására a faj állománya növekedésnek indult. Feltehetően a cserjeirtást követő kaszálások elkezdésével a faj egy stabil populációja alakulhat ki a DéliMátra fátlan élőhelyein. A természetvédelmi kezelések a többi védett és ritka faj számára is kedvező feltételeket biztosíthatnak és az élőhelyek megőrzésével a Sár-hegyre jellemző változatosság és fajgazdagság fenntartható és fokozható.

Köszönetnyilvánitás - Munkánkat a KEOP (Rétek, gyepek, (Fás) legelők helyreállítása és kezelése a BNPI Müködési területén - KEOP-3.1.2/2F/09-2009-0007) projekt részeként végeztük. Köszönettel tartozunk a Bükki Nemzeti Park Igazgatóságnak és munkatársainak, különösképpen Dudás Györgynek, a sokoldalú közremúködésért. Köszönet illeti továbbá Urbán Lászlót és Kemény Attilát a terepmunkákban és a válogatásban nyújtott segítségükért.

\section{Irodalomjegyzék}

Balogh, J. (szerk) (1935): A Sas-hegy pókfaunája. Faunisztikai, rendszertani és környezettani tanulmány. - Sárkány-Nyomda Rt. Budapest, $60 \mathrm{p}$.

Buttler, A. (1992): Permanent plot research in wet meadows and cutting experiment. - Vegetation 103: 113-124. doi: http://dx.doi.org/10.1007/BF00047697 
Bleicher, K., Samu, F., Szinetár, Cs. \& Rédei, T. (1999): A Budai Sas-hegy Természetvédelmi Terület farkaspókjainak (Araneae, Lycosidae) vizsgálata hatvan évvel ezelőtt és napjainkban. Természetvédelmi Közlem. 8: 11-119.

Decleer, K. (1990): Experimental cutting of reedmarsh vegetation and its influence on the spider (Araneae) fauna in the Blankaart naturereserve, Belgium. - Biol. Conserv. 52: 16-185. doi: http://dx.doi.org/10.1016/0006-3207(90)90124-8

Güsewell, S., Buttler, A. \& Klötzli, F. (1998): Short-term and long-term effects of mowing on the vegetation of two calcareous fens. - J. Veg. Sci. 9: 861-872. doi: http://dx.doi.org/10.2307/3237051

Hulbert, L. C. (1988): Causes of fire effects in tallgrass prairie. - Ecology 69: 46-58. doi: http:// dx.doi.org/10.2307/1943159

Ilmarinen, K. \& Mikola, J. (2009): Soil feedback does not explain mowing effects on vegetation structure in a semi-natural grassland. - Acta Oecol. 35: 838-848. doi: http://dx.doi.org/10.1016/j. actao.2009.08.008

Lajos, L. \& Vadkerti, E. (2007): A magyar aknászpók (Nemesia pannonica Herman, 1879) szezonalitás- és társulás- preferencia vizsgálata a Szársomlyón. - Nat. Somogy. 10: 127-133.

Loksa, I. (1984): A magyar aknászpók (Nemesia pannonica Herman) autoökológiája összevetve más Nemesia fajokéval. - Egyetemi Doktori Értekezés, Budapest, 58 p.

Maret, M. P. \& Wilson, M. V. (2000): Fire and seedling population dynamics in western Oregon prairies. - J. Veg. Sci. 11: 307-314. doi: http://dx.doi.org/10.2307/3236811

Noordijk, J., Schaffers, A. P, Heijermanb, T., Boerc, P., Gleichmana M, \& S'ykora, K. V. (2010): Effects of vegetation management by mowing on ground-dwelling arthropods. - Ecol. Eng. 36: 740-750. doi: http://dx.doi.org/10.1016/j.ecoleng.2010.01.003

Pozzi, S., Gonseth, Y. \& Hanggi, A. (1998): Evaluation of dry grassland management on the Swiss occidental plateau using spider communities (Arachnida: Araneae). - Rev. Suisse Zool. 105: 465-485.

Steffan-Dewenter, I. \& Leschke, K. (2002): Effects of habitat management on vegetation and aboveground nesting bees and wasps of orchard meadows in Central Europe. - Biodivers. Conserv. 12: 1953-1968. doi: http://dx.doi.org/10.1023/A:1024199513365

Szinetár, Cs. \& Lajos, L. (2000): A Szársomlyó pókfaunisztikai (Aranea) kutatásának eredményei. - Dunántúli Dolg. Term. Tud. Sorozat. 10: 127-138.

Szinetár, CS., Rákóczi, A. M., Bleicher, K., Botos, E., Kovács, P. \& Samu, F. (2012): A Sas-hegy pókfaunája II. A Sas-hegy faunakutatásának 80 éve a hegyről kimutatott pókfajok kommentált listája. - Rosalia 8: 333-362.

Szmatona-Túri, T. \& Vona-Túri, D. (2012): A magyar aknászpók (Nemesia pannonica Herman, 1879) újabb előfordulása Magyarországon. - Természetvédelmi Közlem. 19: 106-116.

Ysnel, F. \& Canard, A. (2000): Spider biodiversity in connection with the vegetation structure and the foliage orientation of hedges. - J. Arachnol. 28: 107-114. doi: http://dx.doi.org/10.1636/01618202(2000)028[0107:SBICWT]2.0.CO;2 


\title{
The effect of grassland management on abundance of Nemesia pannonica (Herman, 1879) in the Southern Mátra
}

\author{
Tünde Szmatona-Túri ${ }^{1}$, Diána Vona-Túri ${ }^{2}$ and Gábor Magos ${ }^{3}$ \\ ${ }^{1}$ FM ASzK-Forestry, Agricultural and Game Management Secondary School of Mátra, \\ H-3232 Mátrafüred, Erdész Street 11, Hungary \\ ${ }^{2}$ Eötvös József Reformed Education Centre, \\ H-3360 Heves, Dobó Street 29, Hungary \\ ${ }^{3}$ Bükk National Park Directorate, \\ H-3304 Eger, Sánc street 6, Hungary \\ e-mail: turitunde79@gmail.com
}

Our investigation targeted the analysis of the occurences of the protected submediterranean Nemesia pannonica (Herman, 1879) from the Mátra. Moreover the effect of mowing and shrub control on the abundance of the species was examined. The sampling resulted 216 individuals of N. pannonica. Besides males there were females with eggs in the traps. Our research in contrast with previous data prove that the females leave their shaft sometimes. Both grassland management methods have positive effect on abundance of the species therefore one way of the protection of $N$. pannonica is the maintenance and restoration of the habitats.

Keywords: mowing, shrub control, abundance, females 